Jurnal Kesehatan Perintis (Perintis's Health Journal) 7 (1) 2020: 57-63

Contents list available at JKP website

Jurnal Kesehatan Perintis (Perintis's Health Journal)

Journal homepage: https://jurnal.stikesperintis.ac.id/index.php/JKP

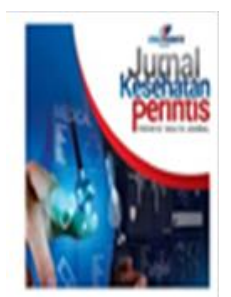

\title{
Viral Load Terhadap Nilai Hematokrit Pada Infeksi Virus Dengue
}

\author{
Rita Permatasari ${ }^{1,2}$, Almurdi Almurdi ${ }^{1}$, Djong Hon Tjong ${ }^{1}$ \\ ${ }^{1}$ Universitas Andalas, Sumatera Barat, Indonesia \\ ${ }^{2}$ STIKes Perintis Padang, Sumatera Barat, Indonesia
}

Article Information :

Submission:May 16, 2020; Revised:Jul 8, 2020; Accepted:Jul 9, 2020; Available online: Jul 12,2020

${ }^{*}$ Corresponding author : Permatasaririta36@gmail.com

\begin{abstract}
ABSTRAK
Demam berdarah adalah suatu penyakit infeksi yang disebabkan oleh virus dengue dan ditularkan melalui gigitan nyamuk Aedes aegypti. Virus dengue yang masuk ke tubuh manusia, akan menyerang sel dendritik dan sel retikuloendotelial lain seperti sel hati, makrofag sehingga menyebabkan diproduksinya mediator imun selular dan humoral. Mediator imun menyebabkan peningkatan permeabilitas kapiler sehingga cairan plasma keluar ke jaringan, akan menyebabkan hemokonsentrasi dan terjadinya peningkatan nilai hematokrit. Tujuan penelitian ini adalah untuk mengetahui hubungan viral load dengan nilai hematokrit pada infeksi virus dengue. Manfaat penelitian ini adalah memberikan penjelasan tentang mekanisme terjadinya infeksi virus dengue yang berpengaruh terhadap jumlah viral load dan nilai hematokrit pada infeksi virus dengue dan dapat digunakan sebagai referensi bagi pembaca maupun peneliti lainnya. Selain itu juga dapat dijadikan sebagai referensi diagnosis penyakit infeksi virus dengue serta meningkatkan kualitas penanganan terhadap penderita infeksi virus dengue. Metode Penelitian dengan desain deskriptif korelasional dengan 49 sampel yang dikumpulkan dari Laboratorium pasien infeksi dengue, data penelitian di analisis dengan software SPSS uji Pearson dengan menggunakan metode NestedqPCR. Hasil Analisis penelitian menggunakan Software SPSS dengan uji korelasi Pearson, didapatkan hubungan jumlah viral load dengan nilai hematokrit pada infeksi dengue sangat lemah dengan nilai koefisien korelasi $r=0,163$ dan nilai signifikan 0,381 $>0,05$. Kesimpulan dari penelitian ini yaitu tidak terdapat hubungan bermakna antara Viral Load Dengan Nilai Hematokrit Pada Infeksi Virus Dengue.
\end{abstract}

Kata kunci : infeksi virus dengue, hematokrit, viral load, nested-qPCR

\section{ABSTRACT}

Dengue fever is an infectious disease caused by dengue virus and is transmitted through the bite of the Aedes aegypti mosquito. Dengue virus that enters the human body, will attack dendritic cells and other reticuloendothelial cells such as liver cells, macrophages, causing the production of cellular and humoral immune mediators. Immune mediators cause an increase in capillary permeability so that plasma fluid comes out into the tissues, causing hemoconcentration and an increase in hematocrit values. The purpose of this study was to determine the relationship of viral load with hematocrit values in dengue virus infection. The benefit of this research is to provide an explanation of the mechanism of dengue virus infection that affects the amount of viral load and hematocrit value in dengue virus infection and can be used as a reference for readers and other researchers. It also can be used as a reference diagnosis of dengue virus infection and improve 
the quality of treatment of patients with dengue virus infection. Method of Research with a descriptive correlational design with 49 samples collected from Dengue infection patient laboratories, the research data were analyzed with the SPSS Pearson test software using the Nested-qPCR method. Results of research analysis using SPSS software with Pearson correlation test, found the relationship of viral load with hematocrit values in dengue infection was very weak with a correlation coefficient $r=0.163$ and significant value $=0.381>0.05$. The conclusion of this study is there is no significant relationship between Viral Load and Hematocrit Value in Dengue Virus Infection.

Keywords : dengue virus infection, hematocrit, viral load, nested-qPCR

\section{PENDAHULUAN}

Penyakit demam berdarah disebabkan oleh virus dengue yang ditularkan nyamuk Aedes aegypti dan Aedes albopictus dan merupakan salah satu penyebab masalah kesehatan utama di Indonesia. Penyakit Demam Berdarah Dengue (DBD) berasal dari genus Flavivirus dengan 4 serotype virus yang berisiko menyebabkan kematian (Prasetyani, 2015).

Berdasarkan data dari Kemenkes RI, DBD termasuk penyakit terbesar kedua di Indonesia pada tahun 2010 dan pada tahun 2011 terdapat 65.432 kasus dan kematian 595 orang. Sementara itu Sumatera Barat menempati urutan kesembilan dengan 2.202 jumlah kasus. Tahun 2013, kasus DBD di Kota Padang yaitu 998 kasus, mengalami peningkatan dibandingkan dua tahun sebelumnya (Arifudin dan Rusjdi, 2014).

Berdasarkan data dari Dinas Kesehatan Kota Padang mengenai gambaran kasus DBD di Kota Padang tahun 2012-2017, diketahui bahwa terjadi peningkatan pada tahun 2015 sebanyak 1.126 orang dibandingkan tahun 2014 sejumlah 666 orang dan mengalami penurunan 608 orang pada tahun 2017 (Dinas Kesehatan Kota Padang, 2017)

Penyebaran penyakit DBD dan peningkatan jumlah penderita dipengaruhi faktor penduduk seperti mobilitas dan kepadatannya (Fridolina Mau dan Loka, 2014) Penyakit ini salah satu penyakit global dengan resiko kematian $1 \%$ dan 2,5 milyar resiko bagi penduduk menderita penyakit ini (Fridolina Mau dan Loka, 2014) Wilayah penyebaran virus dengue yaitu di daerah tropis dan subtropis.

Setiap tahun 50 juta orang menderita penyakit DBD dan melakukan pengobatan rawat inap dimana 500.000 penderita 90\% diderita anak-anak (Candra, 2010).

Pemantauan prognosis penderita DBD dilihat dari pemeriksaan darah dan kriteria laboratorium kebocoran plasmanya dengan adanya peningkatan hemokensentrasi yang menjadi faktor penting (WHO, 2011)

Pada umumnya pendarahan dapat terjadi pada kasus-kasus berat DBD akibat nilai hematokrit yang meningkat, namun terkadang juga mengalami penurunan (Ni Made Renny A Rena, Susila Utama, 2010) Terjadinya peningkatan hematokrit mengikuti perjalanan penyekit dimulai hari ke 3 penyakit dan seterusnya.

Salah satu indikator pemantauan utama dengue yaitu nilai hematokrit (Nasronudin, Widyanti P. Arfijanto MV, 2010) Nilai hematokrit sebagai penanda awal terjadinya renjatan penyakit dan pemeriksaan sederhana dan objektif dalam melihat derajat hemokonsentrasi serta beratnya suatu penyakit (Nurjannah, 2010) Hal utama yang menjadi relevansi penilaian perembesan plasma dan pendeteksian penderita DBD (Raihan, Hadinegoro dan Tumbelaka, 2016).

Faktor yang menentukan viral load dalam darah dipengaruhi oleh efisiensi replikasi DENV di sel dendritik, monosit dan makrofag, serta efisiensi replikasinya di sel endotel dan sel hati. Viral load merupakan faktor resiko dari kasus infeksi DENV yang berat (Waggoner et al., 2020). Infeksi dengue dapat didiagnosa melalui pemeriksaan diagnostik seperti isolasi virus, asam nukleat dengan RT-PCR dan antigen virus sebagai diagnosa infeksi sehingga terlihat fase awal penyakit (Nugraheni et al., 2016).

(Nugraheni et al., 2016) menyatakan replikasi RNA virus dengue plasma lebih tinggi pada pasien DBD dibandingkan pasien Dengue Fever (DF) sedangkan pada saat defervesensi tingkat viral load dengue plasma tidak terdeteksi namun tinggi pada pasien DBD sehingga viral load berkontribusi terhadap patogenesis DBD. Dalam penelitian (McCoy dan Madras, 2020) patogenesis DBD menunjukan adanya ciri khas yang 
dimunculkan oleh penderita DBD salah satunya yaitu terjadinya kebocoran plasma dan viral load plasma yang tinggi dikaitkan dengan infeksi virus DENV-2. Selain itu, dalam penelitian (Srikiatkhachorn dan Spiropoulou, 2014) menunjukan bahwa viral load yang tinggi dan aktivasi sistem kekebalan yang kuat dikaitkan dengan DBD, terbukti karena adanya peran sel-sel endotel dan faktor-faktor yang mengatur permeabilitas vaskular.

Menurut penelitian (Ben-shachar, Schmidler dan Koelle, 2016) menunjukan bahwa pola viral load baik tingkat viral load tinggi maupun penurunan viral load dengue dan waktu peak viremia adalah prediktor yang berguna untuk penyakit berat. Dalam hal ini respon imun seluler berperan penting dalam mengatur viral load infeksi dengue sekunder dan perbedaan serotipe spesifik dalam tingkat infektivitas virus, dengan tingkat infektivitas serotipe 2 dan 3 yang melebihi serotipe 1 . Beda penelitian ini dengan penelitian sebelumnya adalah beberapa peneliti sebelumnya membahas tentang patogenesis infeksi dengue dapat meningkatkan viral load plasma dan adanya faktor permeabilitas vaskuler sebagai penanda keparahan penyakit, namun belum ada penelitian mengenai hubungan dari viral load dengan nilai hematokrit pada infeksi dengue. Pada penelitian ini, untuk melihat hubungan viral load dengan nilai hematokrit pada infeksi dengue. Tujuan penelitian ini melihat hubungan antara jumlah viral load dengan nilai hematokrit pada infeksi virus dengue.

\section{METODE PENELITIAN}

Penelitian menggunakan metode deskriptif korelasional. Jumlah sampel ditentukan sesuai dengan menggunakan rumus besar untuk sampel korelasi tunggal (Madiyono et al.,2010):

$n=\left\{\frac{Z \alpha+Z \beta}{0,5 \operatorname{In}[(1+r) /(1-r)]}\right\}^{2}+3$

$\mathrm{n}$ : besar sampel penelitian

Za: : tingkat kemaknaan yang dinilai tergantung $\alpha$. Untuk penelitian ini $\alpha=$ 0,$005 ; Z \alpha=1,96$

$Z \beta$ : power penelitian yang nilainya tergantung kepada $\beta$. Untuk penelitian ini $\beta=0,8 ; Z \beta=0,842$
$\mathrm{R}$ : perkiraan koefisien korelasi. Untuk penelitian ini $r=0,4$ (Hamed et al., 2013).

In : nilai yang didapat dari tabel In yang besarnya tergantung dari nilai $r$.

Jumlah penelitian 49 sampel yang dikumpulkan dari Laboratorium hasil pemeriksaan pasien infeksi dengue yang telah melakukan pemeriksaan serologi. Penelitian menggunakan metode Nested-qPCR, untuk melihat tipe dengue virus dan pengukuran viral load di analisis dengan realtime PCR absolute quantification melalui kurva response yang melewati nilai ambang batas cycle threshold atau nilai CT, yang dalam hal ini hasil penelitian dianalisis melalui sistem komputerisasi dengan Uji Korelasi Pearson, yaitu Jika nilai sig. < 0,05 maka, dapat disimpulkan bahwa terdapat korelasi yang signifikan antara variabel yang dihubungkan. Sebaliknya, Jika nilai sig. > 0,05 maka, dapat disimpulkan bahwa tidak terdapat korelasi yang signifikan antara variabel yang dihubungkan. Adapun kriteria penilaian koefisien korelasi menurut Colton dalam Sutanto (2007) : 0 (tidak ada korelasi), 0.01 0,25 (korelasi yang sangat lemah), 0,26 0,5 (korelasi lemah, $0,6-0,75$ ) kofelasi kuat, $0,76-0,99$ (korelasi sangat kuat), 1 (korelasi sempurna). Penelitian ini dilakukan di Laboratorium Biomedik Unand, bulan Juni sampai November 2019 dengan pengumpulan sampel bulan Maret sampai Mei 2019. Penelitian ini telah disetujui oleh komite etik FakultasaKedokteranaUnand

(No.268/KEP/FK/2019) yang telah dikaji oleh tim komite etik Fakultas Kedokteran Universitas Andalas melalui protokol penelitian.

Prosedur Pemeriksaan Viral load : (1) Ekstraksi sampel serum pasien dengan menggunakan QIAamp Viral RNA (REF 52904) Mini Kit (QIAGEN) : Buffer AVL diambil $560 \mu \mathrm{L}$ dan mRNA dalam tabung eppendorf $1,5 \mathrm{~mL}$ ditambahkan $140 \mu \mathrm{L}$ sampel serum dan vortex selama 15 detik, inkubasi pada suhu kamar selama 10 menit dan sentrifugasi pada kecepatan $8000 \mathrm{rpm}$, Etanol p.a ditambahkan sebanyak $560 \mu \mathrm{L}$ pada larutan sampel, divortex 15 detik dan disentrifugasi dengan kecepatan 8000 rpm selama 1 menit. Larutan kolom mini QIAamp diambil 630 $\mu$ L, disentrifus 1 menit dengan kecepatan 8000 rpm, solusi yang tersisa dimasukkan ke QIAamp mini coloumn, setelah itu disentrifus 
lagi selama 1 menit dengan kecepatan 8000 rpm, masukkan $500 \mu \mathrm{L}$ buffer AW1, sentrifugasi tambahkan $500 \mu \mathrm{L}$ buffer AW2, disentrifus dengan kecepatan $14.000 \mathrm{rpm}, 3$ menit, pindahkan ke mikrotube $1,5 \mathrm{~mL}$, ditambahkan $50 \mu \mathrm{L}$ buffer AVE, inkubasi pada suhu kamar selama 5 menit, ulangi sentrifus dengan kecepatan rotasi $10.000 \mathrm{rpm}, 2$ menit dan menunjukkan RNA virus (Ansori, A.N.M., Teguh H.S., Pemta, T.D., Nur, L.F.A., Siti, C., Tomohiro, K., Soegeng, 2015). Pengukuran konsentrasi RNA menggunakan Nano Drop 2000 Spectrofotometer (thermoscientific), alat akan mengukur konsentrasi asam nukleat dalam satuan ng/uL. (2) Nested-qPCR Nested-qPCR adalah metoda PCR yang dilakukan sebanyak dua kali, dalam hal ini template PCR pada PCR kedua adalah Pengenceran dari amplikon hasil PCR pertama. PCR pertama dilakukan menggunakan primer dengue outer, ini bertujuan agar semua tipe virus dengue teramplifikasi, selanjutnya dilakukan PCR kedua menggunakan primer forward outer (5'GAGAAACCGCGTGTCAAC-3') dan primer reverse spesifik untuk masing-masing tipe virus dengue, yaitu : DENV1 (5'TTCTTTCTTGAAACTCCGTAGC-3'), DENV2 (5'-GCGGGATTGTTAGGAAACGA-3'),

DENV3 (5'-CTTTTTCCGTCTGTTGATAATGC3') dan DENV4 (5'GACCTATCTCCTTCCTGAATCC AA-3'). (3) Profil Touchdown-qPCR : Metoda penempelan primer yang digunakan adalah touchdown$P C R$, metoda ini menggunakan suhu annealing yang diturunkan secara perlahan, yaitu dari suhu tertinggi hingga suhu terendah yang memungkinkan primer menempel. Tahapan PCR adalah Proses denaturasi awal $95^{\circ} \mathrm{C}$ selama 30 detik, denaturasi $95^{\circ} \mathrm{C}$ selama 5 detik, Annealing $65^{\circ} \mathrm{C}-55^{\circ} \mathrm{C}$ selama 5 detik dan Melt Curve $65^{\circ} \mathrm{C}-95^{\circ} \mathrm{C}$ selama 5 detik (gambar

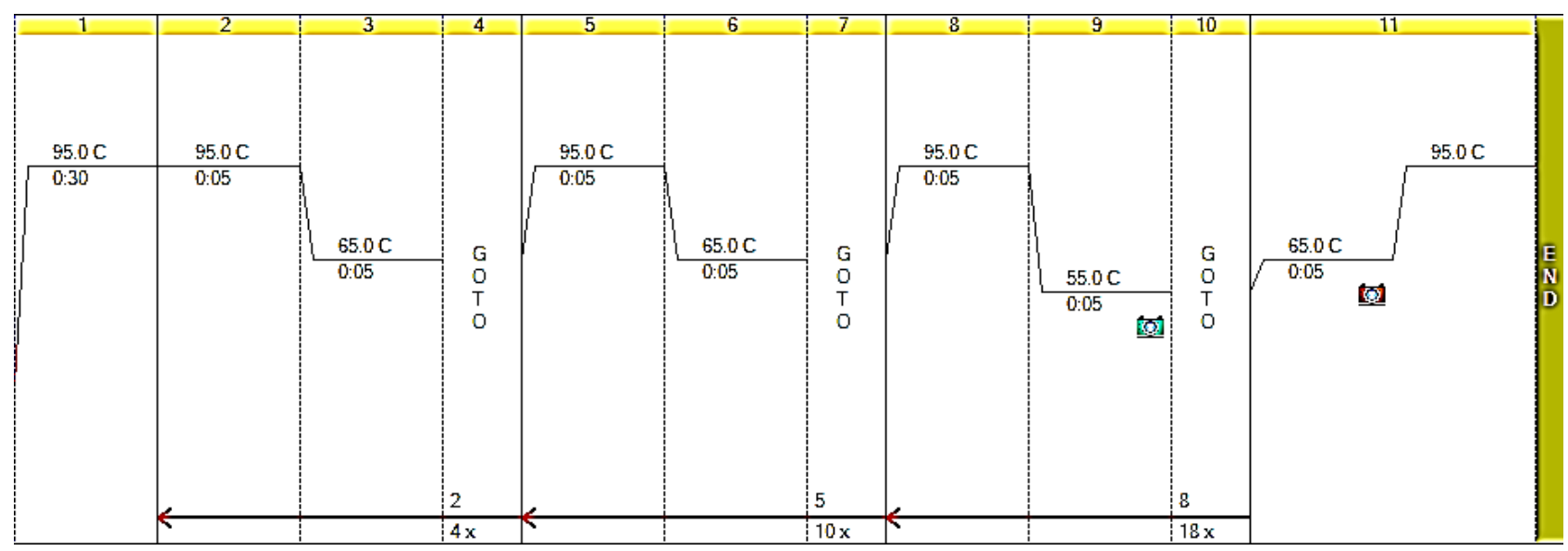

Gambar 1. Profil Touchdown-qPCR

\section{HASIL DAN PEMBAHASAN}

Pada Tabel 1 menunjukkan bahwa bahwa jumlah sampel pada penelitian adalah 49 orang dengan 35 orang $(71,44 \%)$ laki-laki dan 14 orang $(28,56 \%)$ perempuan. Berdasarkan kelompok umur diketahui bahwa usia remaja (12-25 tahun) merupakan jumlah sampel terbanyak 18 orang $(36,73 \%)$, dalam hal ini, remaja perempuan 5 orang $(10,20 \%)$ dan 13 orang remaja laki-laki $(26,53 \%)$. Vektor nyamuk Aedes aegypti aktif menggigit pada siang hari dengan waktu aktif sekitar pukul 08.00-12.00 dan 15.00-17.00 WIB (pusparini, 2014). Pada jam tersebut merupakan waktu aktif bermain di luar rumah dalam hal ini anak laki-laki lebih sering main di luar rumah dibandingkan anak perempuan. Hasil ini didukung oleh penelitian (Livina, Rotty dan Panda, 2013) memperlihatkan penderita terbanyak berjenis kelamin laki-laki sebanyak 42 orang $(54,5 \%)$ dibandingkan penderita berjenis kelamin perempuan yaitu sebanyak 35 orang $(45,5 \%)$ (Livina, Rotty dan Panda, 2013).

Selanjutnya, menurut Raharjanti, et al. (2016) yang menyatakan bahwa jumlah pasien infeksi virus dengue lebih banyak terjadi pada anak laki-laki sebanyak 182 orang (51\%) dibandingkan perempuan sebanyak 177 orang (49\%) (Widyanti et al., 2016) Hasil tersebut 
hampir sama dengan laporan penelitian dibagian IKA RSCM yang mendapatkan perbandingan laki-laki dan perempuan 1,3:1. Hasil penelitian memperlihatkan (Ni Putu Anindya Divy, I Made Sudarmaja, 2018) bahwa kategori jenis kelamin terbanyak adalah jenis kelamin laki-laki. Berdasarkan kelompok usia didapatkan bahwa kelompok usia terbanyak yang menderita infeksi virus dengue pada kelompok usia sekolah yang aktif beraktifitas di luar rumah pada saat jam nyamuk aktif menggigit dan potensi penularan lebih tinggi karena beraktivitas di tempat kepadatan tinggi.

Tabel 1. Distribusi Umur dan Jenis Kelamin Pada Infeksi Dengue Berdasarkan Klasifikasi Umur dan Jenis Kelamin

\begin{tabular}{lcccccc}
\hline \multicolumn{1}{c}{ Umur } & $\mathbf{P}$ & $\mathbf{( \% )}$ & $\mathbf{L}$ & $\mathbf{( \% )}$ & Total & $\mathbf{( \% )}$ \\
$0-5$ & 1 & 2,04 & 2 & 4,08 & 3 & 6,12 \\
$5-11$ & 3 & 6,12 & 3 & 6,12 & 6 & 12,24 \\
$12-25$ & 5 & 10,20 & 13 & 26,53 & 18 & 36.73 \\
$26-45$ & 3 & 6,12 & 9 & 18,37 & 12 & 24,48 \\
$46-65$ & 2 & 4,08 & 8 & 16,33 & 9 & 18.40 \\
Total & 14 & 28,56 & 35 & 71,44 & 49 & 100,00 \\
\hline
\end{tabular}

Keterangan : P : Perempuan, L : Laki-laki

Hal ini disebabkan oleh prevalensi infeksi DENV yang meningkat dan urbanisasi yang cepat dan tidak terkendali, memodulasi faktor iklim, perluasan Aedes aegypti di lingkungan perkotaan (Bhatnagar et al., 2012) Jumlah
Viral Load didapatkan dengan menggunakan metode Nested-qPCR dan Nilai Hematokrit didapatkan dengan menggunakan alat Hematology Analyzer pada Infeksi Dengue dapat dilihat pada (tabel 2):

Tabel 2. Hasil Viral Load dan Nilai Hematokrit

\begin{tabular}{lcccc}
\hline \multicolumn{1}{c}{ Tipe } & Frekuensi & $(\%)$ & $\begin{array}{c}\text { Viral load } \\
\text { Mean } \pm \text { SD }\end{array}$ & $\begin{array}{c}\text { Hematokrit } \\
\text { Mean } \pm \text { SD }\end{array}$ \\
DENV-1 & 12 & 24 & $8,562 \pm 1,788$ & $35,47 \pm 8,78$ \\
DENV-2 & 16 & 33 & $474,415 \pm 0,362$ & $41,94 \pm 3,57$ \\
DENV-3 & 1 & 2 & $8,01 \pm 0$ & $33 \pm$ \\
DENV-4 & 2 & 4 & $8,512 \pm 1,372$ & $38 \pm 8,49$ \\
Tidak terdeteksi & 18 & 37 & & $38,38 \pm 6,93$ \\
DENV & & & & \\
Total & 49 & 100 & & \\
\hline
\end{tabular}

Berdasarkan tabel 2 jumlah Viral Load dengan Nilai Hematokrit diatas dapat diliihat bahwa dari 49 sampel infeksi dengue yang terdeteksi Viral Load sebanyak 31 sampel infeksi dengue menggunakan Nested-qPCR. Hal ini kemungkinan disebabkan oleh hasil validitas interprestasi klinis pemeriksaan infeksi dengue, sehingga ada hasil yang false positive (positif palsu) pada sampel infeksi dengue sehingga saat pemeriksaan dengan qPCR hasil pemeriksaan false positive terlihat oleh karena pemeriksaan secara molekuler merupakan diagnosis utama laboratorium atau gold standar untuk diagnosis virus dengue dan diagnosis sederhana dengan pemeriksaan serologi (Ni Made Renny A Rena, Susila Utama, 2010) Kelemahan pemeriksaan serologi ini diantaranya timbulnya hasil pemeriksaan false positif karena reaksi silang antigen satu dengan yang lainya akibat kesalahan kontrol negatif yang menunjukkan respon positif akibat tidak efektifnya larutan blocking sehingga antigen asing dapat berinteraksi dengan antibodi tertaut enzim sinyal dan timbulnya sinyal yang dapat dideteksi. Berdasarkan Jumlah Viral Load dengan Nilai Hematokrit Tipe DENV yang dilihat dari hubungannya didapatkan bahwa Tipe DENV2 memiliki jumlah viral load tertinggi yaitu nilai mean $474,415 \pm 0,362$, dengan nilai 
hemtokrit yaitu $41,94 \pm 3,57$ dan nilai maximum hematokrit $49 \%$, nilai minimun $21 \%$ serta frekuensi jumlah infeksi berdasarkan tipe DENV paling banyak pada DENV2 16 orang (33\%).

Hematokrit adalah persentase jumlah sel darah merah dengan volume darah total. Peningkatan hematokrit disebabkan oleh tingginya infeksi virus sehingga jumlah viral load dalam darah meningkat yang menyebabkan meningkatnya nilai hematokrit disebabkan oleh adanya respon antibodi yang berperan dalam mengendalikan infeksi dengue, virus dengue yang masuk direspon oleh sel reseptor Fc (FcR) seperti monosit, makrofag, dan sel dendritik, sebagai target alami virus untuk infeksi DENV dengan adanya peningkatan infeksi sel-sel tersebut menyebabkan viral load yang tinggi, menghasilkan aktivasi sel $\mathrm{T}$ yang luas pada awal proses infeksi sehingga terjadinya badai sitokin. Berdasarkan studi klinis telah menunjukkan bahwa sitokin berperan dalam meningkatkan permeabilitas pembuluh darah dengan dilepaskannya sejumlah besar sitokin dan mediator kimia menyebabkan kerusakan sel endotel dan leakage plasma karena pecahnya pembuluh kapiler sehingga darah keluar dari pembuluh darah ke jaringan di luar pembuluh darah dan cairan darah menjadi pekat yang menyebabkan kekentalan darah dan tidak normalnya sel darah merah sehingga kadar oksigen dalam darah rendah yang mempengaruhi nilai hematokrit menjadi meningkat (Wilschut, 2010).

Hemokonsentrasi meningkat pada DBD menjadi indikator penting dalam perembesan plasma (Widyanti et al., 2016). Akibat leakage ini berkurangnya volume plasma mengakibatkan keadaan syok hipovolemik dan terjadinya kegagalan sirkulasi pada penderita. (Martina, 2014) mengungkapkan Virus dengue yang masuk menyerang sel dendritik dan sel retikuloendotel lain seperti sel hati, makrofag sehingga mediator memproduksi imun. Sistem imun manusia ada 2 yaitu selular dan humoral, saat peak viremia dengue meningkat permeabilitas vaskuler juga meningkat akibat dari mediator imun, sehingga cairan plasma dapat keluar ke jaringan. Keluarnya plasma dari tubuh akan menyebabkan hemokonsentrasi yang ditandai dengan peningkatan nilai hematokrit. Ketika perdarahan terjadi, umumnya nilai hematokrit menurun (Ni Made Renny A Rena, Susila
Utama, 2010) Penurunan ini terjadi karena adanya penggantian cairan pada saat infus atau perdarahan (Livina, Rotty dan Panda, 2013) Namun, hematokrit pada hari ketiga sakit meningkat dan terus meningkat salama patogenesis DBD.

Hasil analisis uji statistik terhadap hubungan jumlah viral load dengan nilai hematokrit pada infeksi dengue didapatkan nilai signifikan 0,381 >0,05 sehingga tidak ada perbedaan dan nilai koefisien korelasi $r=$ 0,163 dengan kriteria penilaian koefisisen korelasi yaitu sangat lemah (gambar 2).

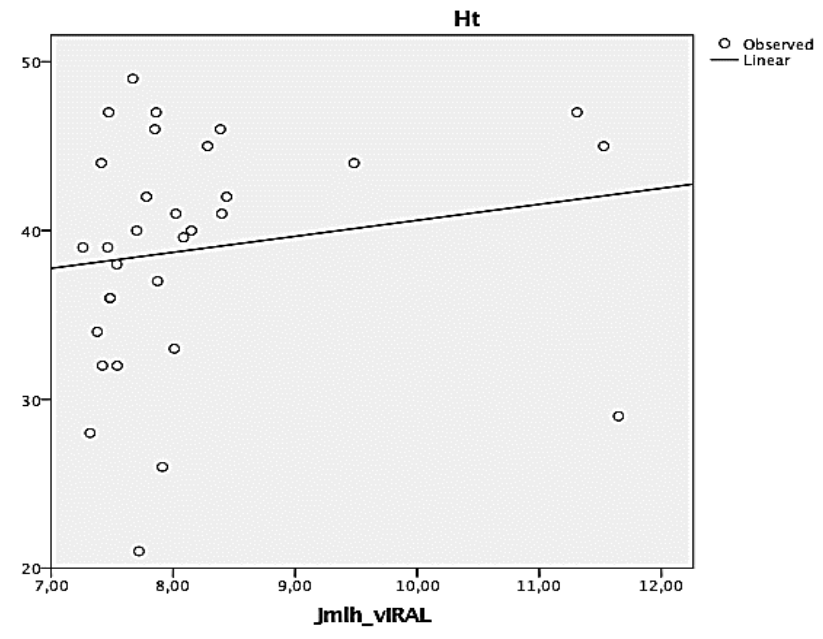

\section{Gambar 2. Grafik Korelasi}

Persamaan garis regresi hasil perhitungan koefisien regresi sederhana memperlihatkan nilai koefisien konstanta adalah 31,12 , koefisien variabel bebas adalah sebesar, 0,948 sehingga persamaan regresi $\mathrm{Y}=31,12+0,948 \mathrm{X}$. Berdasarkan persamaan tersebut nilai konstatanya sebesar 31,12 secara matematis, nilai konstanta ini menyatakan bahwa pada saat variabel bebas 0 maka viral load memiliki nilai 31,12. Selanjutnya nilai positif 0,948 yang terdapat pada koefisien regresi variabel bebas menggambarkan bahwa arah hubungan antara variable bebas dan terikat adalah searah, dalam hal ini setiap kenaikan satu satuan variabel bebas akan menyebabkan kenaikan variabel terikat 0,948 .

\section{KESIMPULAN}

Tidak terdapat hubungan jumlah viral load dengan nilai hematokrit pada infeksi dengue dengan nilai signifikan $=0,381>0,05$ dan nilai koefisien korelasi $r=0,163$ dengan kriteria penilaian koefisisen korelasi yaitu korelasi sangat lemah. 


\section{UCAPAN TERIMA KASIH}

Ucapan terima kasih disampaikan kepada Yayasan Perintis yang telah memberikan dukungan dan bantuan dalam penyelesaian penelitian ini, Laboratorium S3 Bomedik Universitas Andalas atas kerjasamanya dalam membantu penyelesaian penelitian ini.

\section{REFERENSI}

Ansori, A.N.M., Teguh H.S., Pemta, T.D., Nur, L.F.A., Siti, C., Tomohiro, K., Soegeng, S. (2015) "Differences of Universal and Multiplex Primer for Detection of Dengue Virus Differences of Universal and Multiplex Primer for Detection of Dengue Virus from Patients Suspected Dengue Hemorrhagic Fever ( DHF ) in Surabaya," Indonesian Journal of Tropical and Infectious Disease, 5(June), hal. 147-151. doi: 10.20473/ijtid.v5i6.594.

Arifudin, M. dan Rusjdi, S. R. (2014) "Survei Larva Nyamuk Aedes Vektor Demam Berdarah Dengue di Kelurahan Kuranji Kecamatan Kuranji Kotamadya Padang Provinsi Sumatera Barat," Jurnal Kesehatan Andalas, 5(1), hal. 60-66.

Ben-shachar, R., Schmidler, S. dan Koelle, K. (2016) "Drivers of Inter-individual Variation in Dengue Viral Load Dynamics," PLOS Computational Biology, hal. 1-26. doi: 10.1098/rsif.2014.0094.

Bhatnagar, J., Blau, D. M., Shieh, W. J., Paddock, C. D., Drew, C., Liu, L., Jones, T., Patel, M. dan Zaki, S. R. (2012) "Molecular detection and typing of dengue viruses from archived tissues of fatal cases by RT-PCR and sequencing: Diagnostic and epidemiologic implications," American Journal of Tropical Medicine and Hygiene, 86(2), hal. 335340. doi: 10.4269/ajtmh.2012.11-0346.

Candra, A. (2010) "Demam Berdarah Dengue: Epidemiologi , Patogenesis, dan Faktor Risiko Penularan Dengue Hemorrhagic Fever: Epidemiology, Pathogenesis, and Its Transmission Risk Factors," Aspirator, 2(2), hal. 110-119.

Dinas Kesehatan Kota Padang (2017) "Profil Kesehatan Kota Padang Tahun 2017," Dinas Kesehatan Kota Padang, (45), hal. 1-176.

Fridolina Mau, I. I. P. B. S. dan Loka (2014) "Demam Berdarah Dengue Dan Transmisi Transovarial Virus Dengue PadA Aedes spp. Dengue Hemorrhagic Fever And
TransOvarial Transmission Of Dengue Virus In Aedes Spp .," Jurnal Penyakit Bersumber Binatang, 2(1), hal. 1-7.

Livina, A., Rotty, L. W. A. dan Panda, A. L. (2013) "Dan Demam Berdarah Dengue," e-CliniC, 2, hal. 1-8.

Martina, B. E. E. (2014) "Dengue pathogenesis: a disease driven by the host response," Science Progress, 97, hal. 197-214. doi: 10.3184/003685014X14049173153889.

McCoy, B. J. dan Madras, G. (2020) "A review on etio-pathogenesis of dangue fever and its management-an upadate review," International Journal of Chemical Reactor Engineering, 1(1), hal. 1-15.

Nasronudin, Widyanti P. Arfijanto MV, R. M. (2010) "Colloid And Methylprednisolone Therapy As Alternative Manangement Of DHF," Eligible articles, hal. 257-263.

Ni Made Renny A Rena, Susila Utama, T. P. M. (2010) "Kelainan hematologi pada demam berdarah dengue 2 2," Jurnal Penyakit Dalam, 10(September).

Ni Putu Anindya Divy, I Made Sudarmaja, K. S. (2018) "Karakteristik Penderita Demam Berdarah Dengue (Dbd) Di Rsup Sanglah Bulan Juli - Desember Tahun 2014," EJurnal Medika, 7(7), hal. 1-7.

Nugraheni, E., Sulistyowati, I., Mikrobiologi, B., Kedokteran, F. dan Universitas, K. (2016) "Diagnosis Molekuler Virus Dengue Molecular Diagnosis Dengue Virus," JK Unila, 1, hal. 385-392.

Nurjannah (2010) "Faktor-faktor yang berhubungan dengan derajat demam berdarah dengue dbd di kota makassar," Skripsi Fakultas IImu Kesehatan UIN Alauddin Makassar.

Prasetyani, R. D. (2015) "Faktor-Faktor Yang Berhubungan Dengan Kejadian Demam Berdarah Dengue," journal Majority, 4(7), hal. 61-66. Tersedia pada: https://juke.kedokteran.unila.ac.id.

Pusparini (2014) "Kadar hematokrit dan trombosit sebagai indikator diagnosis infeksi dengue primer dan sekunder," JurnalKedokteran Trisakti, 23(2), hal. 5156.

Raihan, R., Hadinegoro, S. R. S. dan Tumbelaka, A. R. (2016) "Faktor Prognosis Terjadinya Syok pada Demam Berdarah Dengue," Sari Pediatri, 12(1), hal. 47. doi: 10.14238/sp12.1.2010.47-52.

Srikiatkhachorn, A. dan Spiropoulou, C. F. 
(2014) "Vascular events in viral hemorrhagic fevers: a comparative study of dengue and hantaviruses," Springer, 355, hal. 621-633. doi: 10.1007/s00441014-1841-9.

Waggoner, J. J., Katzelnick, L. C., BurgerCalderon, R., Gallini, J., Moore, R. H., Kuan, G., Balmaseda, A., Pinsky, B. A. dan Harris, E. (2020) "AntibodyDependent Enhancement of Severe Disease Is Mediated by Serum Viral Load in Pediatric Dengue Virus Infections," The Journal of infectious diseases, 221(11), hal. 1846-1854. doi: 10.1093/infdis/jiz618.

WHO (2011) "Pedoman diagnostik dan tatalaksana infeksi dengue dan demam berdarah dengue menurut pedoman who 2011," hal. 1-42.

Widyanti, T., Raharjanti, M., Alpius, H., Umma, H. A., Siregar, R., Sekadau, K., Barat, K., Widyanti, T., Raharjanti, M., Alpius, H., Umma, H. A. dan Siregar, R. (2016) "Profil Pasien Infeksi Virus Dengue pada Anak di RSUD Sekadau Kabupaten Sekadau Provinsi Kalimantan Barat," Sari Pediatri, 17(132), hal. 379-383.

Wilschut, I. A. R. J. (2010) "Dengue virus life cycle: viral and host factors modulating infectivity," Cellular and Molecular Life Sciences, hal. 2773-2786. doi: 10.1007/s00018-010-0357-z. 